\title{
A figura de Eichmann e a faculdade do pensar em Hannah Arendt
}

\author{
[The FIGURE OF EICHMANN AND HANNAH ARENDT'S FACUlTy OF THINKING]
}

\author{
José Luiz Oliveira * \\ Jhonatan Relher ** \\ Universidade Federal de São João del Rei, Brasil
}

\begin{abstract}
Resumo: Em sua obra Eichmann em Jerusalém: um relato sobre a banalidade do mal, Hannah Arendt (1999) analisa o julgamento de Adolf Eichmann - um ex-oficial do regime nazista responsável pela deportação dos judeus europeus durante o Holocausto, que, por sua vez, se tornou um perito na questão judaica. Durante o seu julgamento, a autora destaca a sua incapacidade de fugir dos clichês burocráticos e sua conspícua superficialidade em condutas convencionais e padronizadas. Diante dessa figura, Arendt se espanta (thaumazein) com a ausência de pensamento nele existente: a falta de parar para pensar. Esse espanto levou Arendt a questionar se teria sido a ausência de pensamento uma das condições capazes de levar o homem a fazer o mal. Nessa perspectiva, este trabalho busca analisar a relação conflitante entre o mal que se torna banal, expresso na figura de Eichmann, e a faculdade humana de pensar, no sentido de se evitarem catástrofes.
\end{abstract}

Palavras-Chave: banalidade; holocausto; julgamento; mal; pensamento
ABSTRACT: In her work Eichmann in Jerusalem: a report on the banality of evil, Hannah Arendt (1999) analyzes the trial of Adolf Eichmann - a former Nazi regime official responsible for the deportation of European Jews during the Holocaust, who, in turn, became an expert on the matter. Jewish. During her trial, the author highlights her inability to escape bureaucratic clichés and her conspicuous superficiality in conventional and standardized conduct. Faced with this figure, Arendt is amazed (thaumazein) with the absence of thought in him: the lack of stopping to think. This astonishment led Arendt to question whether the absence of thought was one of the conditions capable of leading man to do evil. From this perspective, this work seeks to analyze the conflicting relationship between the evil that becomes banal, expressed in the figure of Eichmann, and the human faculty of thinking, in order to avoid catastrophes.

KEYWORDS: banality; holocaust; judgment; evil; thought

\section{INTRODUÇÃo}

Definido como a Era dos extremos pelo historiador Eric Hobsbawm (1995), o século XX foi marcado por grandes catástrofes mundiais, que abalaram as estruturas construídas acerca dos aspectos da vida individual e social na modernidade. Ressalta o autor:

[...] o grande edifício da civilização do século XX desmoronou nas chamas da guerra

* Doutor em Filosofia pela Universidade Federal de Minas Gerais. Pós-doutorado em Filosofia pela Universidade federal de Minas Gerais. Professor Associado III do Departamento de Filosofia e Métodos da Universidade Federal de São João del-Rei.Email: jlos@ufsj.edu.br. ** Universidade Federal de São João Del-Rei.Email: jhonatan.relher@gmail.com 
mundial, quando suas colunas ruíram [...]. Sua história e, mais especificamente, a história de sua era inicial de colapso e catástrofe devem começar com a da guerra mundial de 31 anos. Para os que nasceram antes de 1914, o contraste foi tão impressionante que muitos [...] se recusaram a ver qualquer continuidade com o passado. 'Paz' significava 'antes de 1914': depois disso veio algo que não merecia esse nome. Era compreensível (HOBSBAWM, 1995, p. 30).

Nesse cenário, delineou-se o nazifascismo na Europa, com o qual Hannah Arendt teve contato in vita. Posteriormente, dedicou seus estudos a compreender o fenômeno do totalitarismo, que se engendrou na história humana, gerando marcas profundas na esfera pública e privada.

Após o fim da Segunda Guerra Mundial, muitos nazistas foram a julgamento pelos crimes que cometeram durante esse período - como crimes de guerra e contra a humanidade ${ }^{1}$. Diante desse contexto, Arendt esteve no julgamento de um oficial nazista em Jerusalém. A presença da pensadora nesse julgamento foi na condição de correspondente do jornal The New Yorker. Esse era Adolf Eichmann, responsável pela deportação dos judeus no Terceiro Reich ${ }^{2}$, que culminou com a execução ou trabalho forçado de inúmeros judeus.

Como espectadora ${ }^{3}$ atenta ao julgamento, Arendt esperava estar diante de um homem com fortes traços patológicos, no qual se apresentasse, de modo evidente, o mal que fora por ele praticado por meio de uma articulação protuberante. Todavia, a figura que se apresentava era de um indivíduo, cujos recursos de linguagem eram limitados. Para tanto, recorria sempre aos clichês burocráticos mesmo que isso fosse sinal de contradição para ele dentro do julgamento. Ficava evidenciada, portanto, a conspícua superficialidade de Eichmann ao não conseguir executar uma análise profunda dos seus atos - dos quais ele tinha consciência - e da sua vontade de estar sempre sob ordens e autoridades burocráticas que o regulamentariam.

Nessa perspectiva, a pensadora se espantou (thaumazein) diante do aspecto manifestado em Eichmann: sua condição de não pensar. A partir de então, Arendt (2009) dedicou-se a analisar o que se entendia por pensamento na História da Filosofia, principalmente em sua obra A Vida do Espírito, e fez inúmeras análises de acordo com o seu "espanto" inicial. Outrossim, a questão que a norteou foi se o não pensar era o fator que sobressaía para que o indivíduo praticasse o mal. Já que o pensamento é uma atividade do espírito que empreende uma busca constante de sentido em um diálogo claro entre o sujeito e o ego pensante, dissolver-se-ia, assim, todo princípio relativo ao problema do mal, visto que este não é radical, e sim superficial ${ }^{4}$.

\section{QUEM FOI EICHMANN}

Em sua obra Eichmann em Jerusalém: um relato sobre a banalidade do mal, Hannah Arendt (1999) pormenoriza os fatos centrais da vida do réu em consonância com o que foi dito por ele em depoimento. Nascido na Alemanha, Adolf Eichmann fora um estudante mediano, sem um notório arcabouço intelectual, motivo pelo qual seu pai retirou-o da escola secundária e depois da escola vocacional (ARENDT, 1999, p. 40). Sem perspectiva alguma de carreira, Eichmann passou cinco anos e meio de sua vida na Companhia de Óleo a Vácuo. Em um momento histórico de desemprego, ele ganhava bem, morava com seus pais e, comumente, fazia viagens a trabalho.

Arendt (1999, p. 32) relata que, em abril de 1932, o acusado iniciou sua carreira nos moldes do Estado Nazista filiando-se ao Partido Nacional Socialista. Sete meses depois, ingressou na SS - Schutzstaffel (Tropa de Proteção) 5 . No entanto, Eichmann 
não entrou no Partido por convicção nem jamais se deixou convencer por ele [...]. Ele não tinha tempo, e muito menos vontade de se informar adequadamente, jamais conheceu o programa do Partido, nunca leu 'Mein Kampf'. Kaltenbrunner disse para ele: Por que não se filia à SS? E ele respondeu: Por que não? Foi assim que aconteceu, e isso parecia ser tudo (ARENDT, 1999, p. 44).

Por outro lado, a pensadora destaca que ele sempre fora ambicioso e que o seu emprego na Companhia de Óleo a Vácuo não o satisfazia mais. A entrada no Partido era tida, assim, como um possível futuro promissor, em que poderia construir carreira. De fato, a partir do momento em que se mudou para a Alemanha em 1933, ficou nos campos militares e alcançou o grau de cabo - Scharführer. Contudo, segundo ele, a vida no serviço militar era movida pela rotina, por isso já não a suportava mais (ARENDT, 1999, p. 46).

Com tal visão, Eichmann candidatou-se ao Serviço de Segurança da Reichsführer $\mathrm{SS}^{6}$ (SD) e, novamente, demarcava a aparência de não conhecer o teor do órgão no qual ingressava. Necessitou, pois, começar do zero, inicialmente no Departamento de Informação, com a função de arquivar tudo que era relativo à maçonaria e auxiliar na montagem de um museu acerca desta; posteriormente, conforme salienta Arendt (1999, p. 49), foi transferido para o recém-criado departamento responsável pelos assuntos judaicos.

Entretanto, nas palavras de Souki (1998, p. 95), "ele nunca deixou de ser tratado na SS como pessoa socialmente inferior e nunca conseguia falar de sua mágoa em relação aos 'cavalheiros' da alta classe média, apesar de conseguir mandar milhões de pessoas para a morte”. Sua aspiração era o sucesso, e era essa a possibilidade que vislumbrava desde quando ingressou nos órgãos da organização nazista bem como nos seus movimentos de ascensão de cargos. Saíra de uma vida sem significado, segundo suas concepções, para o evento da História, que poderia lhe possibilitar começar e construir algo novo, destoante do fracasso em relação à sua classe, à sua família e a si próprio (ARENDT, 1999, p. 45).

A partir disso, começava a se esboçar o que levaria Eichmann ao julgamento assistido por Arendt. Enquanto esteve nesse departamento, começou a se especializar nos assuntos relativos ao sionismo embora não se tornara uma autoridade no assunto. Leu os livros Der Judenstaat, de Theodor Herzl, e História do Sionismo, de Josef Böhm. "Daí em diante, conforme repetiu insistentemente, ele não pensava em nada além de uma 'solução política' (por oposição à posterior 'solução física' sendo que a primeira significava expulsão e a segunda extermínio) e em como 'conseguir alguma base sólida para os judeus" (ARENDT, 1999, p. 53). Com isso, alcançou uma indicação como espião dos escritórios sionistas e de suas reuniões, dando-lhe a promoção a oficial-tenente na chefia do Centro de Emigração de Judeus Austríacos em Viena (1938) (ARENDT, 1999, p. 56).

Por meio de sua capacidade de organizar e negociar, Eichmann correlacionou as negociações com representantes judeus - convencendo-os da emigração - à questão financeira solucionada por Heydrich ${ }^{7}$. Por fim, acelerou a questão burocrática e jurídica, possibilitando que a emigração acontecesse de forma mais rápida e prática ${ }^{8}$ (ARENDT, 1999). Esse é um marco peculiar do período da Segunda Guerra e caro a indivíduos como Eichmann, pois se "exige a organização e administração - mesmo sendo o seu objetivo a destruição racionalizada de vidas humanas da maneira mais eficiente, como nos campos de extermínio alemães" (HOBSBAWM, 1995, p. 52).

Porém, conforme analisa Arendt (1999), diante desse cenário internacional de guerra e da anexação dos territórios poloneses, a emigração forçada - que valera tantos esforços de Eichmann - chegou ao seu esgotamento. Logo, caberia esboçar e pôr em prática planos para poder evacuar essa população judaica. No entanto, essas estratégias serviram apenas como forma de encobrir os preparativos para o extermínio físico dos 
judeus de toda a Europa Ocidental.

O extermínio físico era a chamada "solução final", da qual o acusado é responsabilizado, uma vez que, em 1941, Eichmann foi enviado para supervisionar o campo de concentração que se fundara em Theresienstadt no período caracterizado por Arendt como "concentração" (ARENDT, 1999, p. 82). Nesse momento, ele já sabia das ordens de Hitler acerca da solução final e havia começado, há pouco tempo, suas visitas para inspecionar centros de extermínio, como em Treblinka, Kulm e Minsk. Enquanto supervisor desse campo, o réu sabia que funcionara como ponto de concentração para uma posterior deportação de judeus aos locais de extermínio e trabalhos forçados.

É notório, nessa perspectiva, que ele era culpado dos crimes em total medida, ainda que se considerasse inocente no sentido da acusação, porque se entendia apenas como um subordinado às ordens que lhe foram dadas. Assim, "insistiu veementemente que era culpado apenas de ajudar e instigar a realização de crimes de que era acusado" (ARENDT, 1999 , p. 268). Analisando tal comportamento, Arendt (1999, p. 268, grifo da autora) sustenta, por meio do relato da sentença do julgamento, que,

\begin{abstract}
em tal enorme e complexo crime como este que estamos agora considerando, no qual muitas pessoas participaram, em vários níveis e em várias espécies de atividade - os planejadores, os organizadores, e aqueles que executavam os atos, segundo seus vários níveis -, não há muito propósito em se usar os conceitos normais de aconselhar e assistir à perpetração de um crime. Pois esses crimes foram cometidos em massa [...] e na medida em que qualquer um dos criminosos estava próximo ou distante do efetivo assassinato da vítima nada significa no que tange à medida de sua responsabilidade. Ao contrário, no geral o grau de responsabilidade aumenta quanto mais longe nos colocamos do homem que maneja o instrumento fatal com suas próprias mãos.
\end{abstract}

Por esse viés, percebe-se que, no tangente à responsabilidade pelos crimes cometidos, todos os envolvidos têm a sua incumbência mesmo que não fossem autores diretos dos golpes letais. Eichmann e tantos outros eram indivíduos comuns com características semelhantes às descritas no relato da sentença, que, por suas ações e omissões, foram peças conscientes para um dos maiores genocídios da história humana. À vista disso, as maiores crueldades desse período foram impessoais, deliberadas à distância por meio de sistemas de rotina, notoriamente justificadas como necessidades operacionais (HOBSBAWM, 1995).

\title{
O ESPANTo (THAUMAZEIN) DE ARENDT
}

Diante do exposto sobre o acusado e como ele próprio se via nos crimes cometidos pelos nazistas, legitima-se o questionamento içado por Arendt (1999, p. 106) em sua obra: ele sabia realmente o que estava fazendo e estaria ele em posição de julgar seus feitos? Embora não tenha participado do extermínio in persona, esteve, de forma atuante, no transporte dos judeus, sabendo quais seriam os seus destinos, pois os havia visitado como mencionamos anteriormente.

Todavia, a figura que se apresentava no julgamento não era a de um homem extremamente articulado, que demonstrava reflexão dos seus atos à iminência de julgá-los com eficácia. Era um indivíduo comum, longe da configuração de um monstro ou de um agente demoníaco, que dominou o imaginário social quando foi divulgado o julgamento após sua captura. Dessa maneira, "nele não se encontrava sinal de firmes convicções ideológicas ou de motivações especificamente más" (ARENDT, 2009, p. 18), o que criava uma ruptura com a percepção preestabelecida acerca do réu. 
A autora fez uma densa inspeção acerca do comportamento de Eichmann durante o julgamento. Nesta, destaca-se o uso de clichês a que sempre recorria para mencionar os acontecimentos que julgava importantes e para se referir a algum incidente ocorrido. Independentemente do contexto ou local, evocava as mesmas frases feitas e os seus clichês "semi-inventados". Eichmann se limitava àquilo que lhe proporcionava uma "sensação de ânimo" quando era necessário recorrer à sua memória nos momentos decisivos da questão do extermínio judeu. Nesse contexto, Arendt (1999, p. 66) afirma:

Por isso, durante o interrogatório, toda vez que os juízes tentavam apelar para sua consciência, recebiam como resposta o 'ânimo' e ficavam ultrajados e desconcertados quando descobriam que o acusado tinha à sua disposição um clichê de ânimo diferente para cada período de sua vida e cada uma de suas atividades. Na cabeça dele, não havia contradição entre 'vou dançar no meu túmulo, rindo', adequado para o fim da guerra, e 'posso ser enforcado em público como exemplo para todos os antissemitas da Terra', que agora, em circunstâncias muito diferentes, preenchia a mesma função de lhe dar um empurrão.

É importante ressaltar que Eichmann evocava, ademais, lembranças com a intenção de ressaltar a sua própria carreira mesmo que isso significasse um ato de contradição e incoerência dentro de suas falas e relatos de memória. Isso demarca certa ignorância e irreflexão ao passo que, com isso, não se defendia daquilo que o acusavam em julgamento. Revela-se, assim, a superficialidade do acusado por meio de suas condutas convencionais e padronizadas, expressas em sua incapacidade de fugir dos clichês.

Fica evidente que Eichmann se encontrava dentro do arquétipo típico dos indivíduos envolvidos com a dinâmica de um regime totalitário, percebendo-se apenas como uma peça de uma engrenagem, que, para Arendt (1999), é inadmissível. Tratava-se de manifestações que o enquadravam na mesma espécie de comportamento dos adeptos às regras de linguagens, que almejavam manter a ordem e o equilíbrio dos serviços do Reich, normalizando a noção de assassinato e mentira ${ }^{9}$. Nesse sentido, como salienta Souki (1998, p. 97):

A linguagem de Eichmann é o tipo perfeito do que se pode chamar de 'linguagem burocrática', aquela cuja função fundamental é criar uma apaziguadora ilusão para os executores e para os executados, pois estes últimos nem de longe entendem o significado dessas palavras.

O comportamento do réu, conforme apontado, causou um grande espanto em Arendt consoante à categorização de thaumazein como "o choque da admiração diante do milagre do Ser (the shocked wonder at the miracle of Being)" (ARENDT, 1998, p. 302). Estava claro em sua percepção que o agente, por meio de sua severa superficialidade, era impossibilitado de se deter ao mal dos seus atos e à sua profundidade motivacional. Desconstruindo a imagem de um homem extremamente articulado para o mal, "a única característica notória que se podia perceber tanto em seu comportamento anterior quanto durante o próprio julgamento e o sumário da culpa que o antecedeu era algo de inteiramente negativo: não era a estupidez, mas a "irreflexão" (ARENDT, 2009, p. 18).

Ao tangente a esse apanágio, pode-se compreender, segundo a esteira de pensamento de Schio (2011, p. 130), que "ele não se questionou sobre o que fazia, ou por que agia daquela maneira e não de outra, e, por isso, não conseguiu perceber que o conjunto de regras, valores, hábitos, e outros, da tradição, haviam sido alterados, pervertidos pelo sistema vigente". O que fez Eichmann diante de tal contexto foi se adaptar ao conjunto moral presente e aplicá-lo a todas as conjunturas.

A notória incapacidade de reflexão, dessa forma, provocou em Arendt indagações acerca da faculdade do pensar e sua atividade. Percebendo que há no homem certa 
exigência de atenção do pensamento para todos os fatos e acontecimentos que circundam a vida humana, a autora concluíra que o réu não teria tomado conhecimento dessa exigência (ARENDT, 2009). Por outro ângulo, como mesmo se definia e aparentava, ele vivia cumprindo regras em um estilo de existência altamente burocratizada. No entanto, como ressalta Arendt (2009, p. 41):

[...] a verdade é que não só as aparências nunca revelam espontaneamente o que se encontra por trás delas, mas também que, genericamente falando, elas nunca revelam apenas; elas também ocultam - 'nenhuma coisa, nenhum lado de uma coisa se mostra sem que ativamente oculte os demais'. As aparências expõem e também protegem da exposição [...].

Eichmann ocultava, dessa maneira, por detrás de sua vida regida pelos estatutos simbólicos e objetivos do Estado Nazista, os seus desejos ambiciosos e a sua busca por uma vida que fugisse da monotonia para alcançar determinado estilo e estabilidade que desejara - o que não anula, todavia, a capacidade de reflexão inerente a todo ser humano. Ou seja, ao aparentar a todos o típico homem trabalhador empregado nos serviços do Estado, que tinha por princípio seguir as ordens e leis, ocultava um indivíduo que visava às suas ânsias vaidosas de sucesso pessoal, com uma latente incapacidade de reflexão. Nesse ínterim,

[...] nem o praticante de boas ações, que precisa ocultar sua individualidade e manter-se em completo anonimato, nem o criminoso, que precisa esconder-se dos outros, pode correr o risco de revelar-se. Ambos são indivíduos solitários [...] ficam, portanto, fora do âmbito do intercurso humano e são figuras politicamente marginais que, em geral, surgem no cenário histórico em épocas de corrupção, desintegração e decadência política (ARENDT, 2007, p. 192-193).

Cabe analisar, destarte, as considerações arendtianas acerca do fenômeno do pensamento e quais seriam as implicações de seu vazio - o não pensar. Visto que se pressupunha a sua íntima relação com a prática do mal efetuada pelo homem, o vazio de pensamento possui, por consequência, a potencialidade de ser o ponto nodal da gênese de figuras como Eichmann, célebres em sociedades massificadas.

\section{A FACULdADE DO PENSAR}

Em sua obra A Vida do Espírito, Hannah Arendt (2009) dedicou-se a investigar o que se entendia por pensamento na História da Filosofia e fez inúmeras análises de acordo com o seu "espanto" inicial ocorrido durante o julgamento. As questões acerca dessa faculdade encontram-se desde a gênese da filosofia, na qual, inicialmente, entrelaçadas à metafísica, constaram-se como constituinte da parte superior da dicotomia "(verdadeiro) Ser e (mera) Aparência”.

Situando-se num espaço de questionamento às antigas elaborações da metafísica, Arendt (2009, p. 27) conduz suas análises pelo que denominou de "falácias metafísicas", cujo objetivo calca-se em recobrar o significado do pensamento. Para tanto, ela reconhece a importância das aparências, ou seja, daquilo que se expõe no mundo sensível em toda sua relação fenomênica, para, dessa forma, chegar à atividade espiritual do pensamento mediante a coincidência - para os seres humanos - entre Ser e Aparecer (ARENDT, 2009). Embora muito já se destacasse a respeito desse tema, poucos foram os pensadores que, de fato, ressaltaram o que os fizeram pensar e analisaram as suas experiências durante esse momento.

Arendt (2009) destaca o surgimento histórico do pensamento sob duas vertentes. A primeira delas é a grega, a qual é sustentada pelo espanto admirativo "diante do espetáculo 
em meio a que o homem nasceu e para cuja apreciação ele está tão bem equiparado de corpo e espírito", fundamentado, primeiramente, por Platão (ARENDT, 2009, p. 184). A segunda partiu do pressuposto romano, defendida por Epiteto, que se refere ao "extremo terrível de ter sido jogado em um mundo cuja hostilidade é assustadora, onde o medo predomina e de onde o homem tenta escapar o máximo" (ARENDT, 2009, p. 184). Embora destoantes entre si, existe a concordância em que o pensamento deixa o mundo das aparências, partindo em direção ao mundo suprassensível, que corresponde ao mundo das ideias, no primeiro caso, ou a um lugar de efetiva retirada radical da realidade, onde há a "impressão" (ARENDT, 2009, p. 177) dos objetos percebidos, defendidos pelos romanos.

Ademais, a pensadora procura em Sócrates o aporte teórico para tentar responder à questão: "O que nos faz pensar?", de modo que o ego pensante seja revelado e possa se averiguar como provocar a sua manifestação. Por esse viés, estabelecem-se as indagações socráticas a respeito dos conceitos, como, por exemplo, o que são a justiça, a amizade, a piedade e a coragem. Essa busca, segundo Arendt (2009), desfaz aquilo que a linguagem solidificou e segue em direção ao seu significado original, desfazendo os velhos preceitos já estabelecidos e construindo outros, embora os últimos não estejam imunes a novos questionamentos. Por conseguinte, "só os objetos do pensamento, mas nunca a atividade de pensar, ficam além do movimento e da perecibilidade" (ARENDT, 2007, p. 313).

O pensamento segue, portanto, como uma busca de significado, que, por natureza, é dinâmica; ou seja, aquilo que se pensa hoje, via de regra, não corresponderá às necessidades do espírito noutro dia posterior ${ }^{10}$. Assim, não cabe ao pensamento criar doutrinas e novos credos como parâmetro de vida; ao contrário, é próprio dele confrontar tudo aquilo que já se tornou convencional na vida humana. Dessa maneira, ressalta Arendt (2009, p. 197):

[...] o pensamento tem inevitavelmente um efeito destrutivo e corrosivo sobre todos os critérios estabelecidos, valores, padrões para o bem e para o mal, em suma, sobre todos os costumes e regras de conduta com que lidamos em moral e ética. Estes pensamentos congelados, Sócrates parece dizer, ocorrem tão facilmente que até dormindo podemos fazer uso deles; mas se o vento do pensamento que agora provoquei sacudiu você do seu sono e deixou-o totalmente desperto e vivo, você verá que pode dispor apenas de perplexidades, e o melhor que se pode fazer com elas é partilhá-las com os outros.

Neste movimento constante de retirada em direção ao eu, conjuga-se ao espírito uma reação de perplexidade, conforme apontado pela autora, diante daquilo que o pensamento desperta - indagações, às quais o indivíduo procura dar conta em sua existência como tal. Essa perplexidade gera no sujeito inquietações durante os processos vitais, colocando-o em estado de análise crítica, seja da sua vida enquanto indivíduo, seja dos processos políticos que o cercam e o integram. De fato, como crê Heidegger, segundo a interpretação arendtiana, o pensamento não traz conhecimento como as ciências, não produz sabedoria prática utilizável, não resolve enigmas do Universo e não dota os seres humanos diretamente com o poder de agir (ARENDT, 2009). Isso demarca que existe no homem uma necessidade de pensar, para além dos limites do conhecimento, algo que esteja para além do conhecer e agir (ARENDT, 2009), introduzindo-se, geralmente, depois desse empenho, certa desconfiança e insegurança perante aquilo que parecia indubitável.

Em relação à experiência, Arendt (2009) trata o pensamento enquanto uma das atividades do espírito, constatando que, durante esse processo, se interrompe toda ação e ocupações habituais, elevando o espírito à condição de parar para pensar. A essência dessa atividade consiste naquilo que Sócrates nomeou de “dois-em-um". Em outras palavras, esse exercício é possibilitado pela dualidade do eu consigo mesmo, em que ao mesmo tempo é o sujeito que pergunta e é ele mesmo quem responde (ARENDT, 2009). Por esse viés, Souki (1998, p. 123) comenta que 
a realização, especificamente humana, da consciência no diálogo pensante de mim comigo mesmo sugere que a diferença e a alteridade, características tão destacadas do mundo das aparências tal como é dado ao homem, seu habitat em meio a uma pluralidade de coisas, são também as mesmas condições da existência do ego mental do homem, já que ele só existe na dualidade.

Para compreender esse pressuposto socrático, faz-se necessário destacar esta diferença subjetiva humana que se dá entre pensamento e consciência: a consciência age com intencionalidade por meio da cognição, já o pensamento é um diálogo com a consciência, ou seja, entre o ego pensante e si mesmo. Sem a consciência, o ato de pensar não seria possível. Por conseguinte, nenhum sujeito que pensa estaria sozinho, pois sempre estaria em companhia de um parceiro, como destaca Sócrates, cabendo àquele que pensa o cuidado para que sempre sejam "amigos", isto é:

Quando Sócrates vai para casa, ele não está solitário, está junto a si mesmo. Evidentemente Sócrates tem que entrar em alguma espécie de acordo com o sujeito que o espera, já que eles vivem sob o mesmo teto. É melhor se desavir com o mundo todo do que com aquela única pessoa com quem se é forçado a viver após ter-se despedido de todas as companhias (ARENDT, 2009, p. 211, grifo da autora).

Destarte, a capacidade humana de pensar não se limita a alguns poucos, como os pensadores profissionais kantianos (Denker Von Gewber), que se dedicam estritamente às atividades espirituais (ARENDT, 1993, p. 151). Visto que essa é uma inclinação inerente a todos os seres humanos, há a possibilidade de que cada indivíduo em sua existência possa buscar este "diálogo mudo" que se dispõe a analisar os julgamentos e as ações.

\section{BANALIDADE DO MAL E IRREFLEX̃̃O}

Diante da condição humana do pensar, cujos resultados tendem ao aprimoramento da consciência moral, cabem os seguintes questionamentos: se todos possuem essa capacidade e a atividade do pensamento é tão avassaladora, como podem, portanto, existir os atos maus? Seria ela uma condicionante para os homens não fazerem o mal?

A autora compreende que o mal, evidenciado no caso Eichmann, distancia-se da concepção ontológica, diabólica ou alguma categoria de sadismo. Ele se inclina à negação da humanidade do outro de que ele possa ser e agir no mundo comum; ou seja, "quando o ser humano, singular, irrepetível e com igualdade perante os outros porque é humano, é ultrajado, desrespeitado, e até morto" (SCHIO, 2011, p. 132). Por conseguinte, esse mal torna-se político, porque "atinge o íntimo do ser e da própria humanidade nele contida, que pode ser repetível, gigantesco em suas proporções e resultados [...]" (SCHIO, 2011, p. 132).

Dentro dessa concepção, Arendt (1999, p. 167, grifos da autora) conclui que o Mal na Alemanha nazista não possuía, por ora, o seu caráter de reconhecimento geral - a tentação. Explica a autora:

Muitos alemães e nazistas, provavelmente a esmagadora maioria deles, deve ter sido tentada a não matar, a não roubar, a não deixar seus vizinhos partirem para a destruição [...], e a não se tornarem cúmplices de todos esses crimes tirando proveito deles. Mas Deus sabe como eles tinham aprendido a resistir à tentação.

Por meio dessa novidade posta pelo totalitarismo, Arendt (1999) introduz o conceito de mal banal para apontar o fenômeno que se manifestou durante o julgamento, no qual o mal se apresenta pelo descompasso existente entre a superficialidade do agente e a proporção dos crimes realizados. Em Eichmann, existia, pois, a demonstração de como 
um indivíduo trivial pode cometer tamanha barbárie.

A fim de elucidar a banalidade envolta em tais ações, Arendt (2009, p. 201) busca demonstrar como esse novo fenômeno não possui raízes arraigadas na subjetividade humana, como, por exemplo, é pressuposto no mal radical kantiano. Assim, ela encontra no eros admitido por Sócrates o ensejo que fundamenta o pensamento em detrimento do mal. O eros é a manifestação do amor, no sentido grego, àquilo que falta - o desejo ao que não se tem. Relacionando-o diretamente à busca empreendida pelo pensamento, Arendt (2009, p. 201) descreve:

Ao desejar o que não tem, o amor estabelece uma relação com o que não está presente. Para trazer à luz e fazer aparecer essa relação, os homens procuram falar dela - assim como o amante procura falar do amado. É porque a busca empreendida pelo pensamento é um tipo de amor desejante que os objetos do pensamento só podem ser coisas merecedoras de amor [...].

Dessa maneira, o pensamento se assemelha ao eros, pois, também, é a busca de algo que não se tem por completo, ou seja, o significado das ações próprias ou do mundo que rodeia os sujeitos. Visto que esse empreendimento, por natureza, tem capacidade destrutiva sobre as concepções, ao se refletir sobre os atos e conceitos maus bem como sobre suas possibilidades, dissolver-se-ia até a sua falta original, porque o mal, por si só, não possui raízes quando posto à reflexão.

O mal compreendido na filosofia arendtiana, nesse ensejo, engendra-se com a fuga da contradição interna devido às ações bastante fatuais, como, por exemplo, as relacionadas com as ordens gerais que conduziam inúmeras pessoas à morte. Esses casos se repetem nos regimes totalitários e em sociedades de massas, onde se irradiam as implicações causadas pelo não pensar - desde os simples indivíduos que se submetem ao poder do Estado aos altos burocratas: "O súdito ideal do governo totalitário não é o nazista convicto nem o comunista convicto, mas aquele para quem já não existe diferença entre o fato e a ficção (isto é, a realidade da experiência) e a diferença entre o verdadeiro e o falso (isto é, os critérios do pensamento)" (ARENDT, 1989, p. 526). Com efeito, ao observar tais características imbricadas no mal insurgente em Eichmann, Adriano Correia (2013, p. 75) explana:

O seu déficit moral, por assim dizer, se assenta na sua incapacidade de avaliar a desproporção entre estes dois termos: eficiência na sua função (aliada ao reconhecimento público) e a consequente destruição gratuita (que vai contra tudo o que já pôde conceber mesmo o utilitarismo mais rasteiro). A sua incapacidade consistia, por exemplo, em não perceber que os seus atos, ainda que compatíveis com a ordem moral, jurídica e social instaurada pelo nazismo, não seriam coadunáveis com qualquer contexto moral, jurídico ou social até então existente ou imaginado.

O não pensar pressupõe, então, que os sujeitos não tenham a interpelação consigo mesmo, ao passo que respalda a incapacidade do indivíduo, conforme citado, de avaliar suas condutas dentro das ordens vigentes. Desse modo, propicia-se ao homem a sensação de liberdade frente à perturbação evocada pela contradição, pois é a consciência moral aquela que "deixa um homem repleto de embaraços" (ARENDT, 2009, p. 213), segundo a interpretação arendtiana de Shakespeare ${ }^{11}$. É o amigo - parceiro no diálogo interno - citado por Sócrates que irá cobrar do indivíduo a plausibilidade de suas ações más, gerando, por conseguinte, uma contradição no espírito humano. Logo, há no homem uma testemunha de tudo aquilo que ele fez e disse, e ela estará lá todas as vezes que este executar a atividade do pensamento. Nas palavras de Arendt (2009, p. 213, grifo da autora): 
Uma pessoa que não conhece essa interação silenciosa (na qual examinamos o que dizemos e fazemos) não se importa em contradizer-se, e isso significa que ela jamais quererá ou poderá prestar contas do que faz ou diz; nem se importará em cometer um crime, já que pode estar certa de esquecê-lo no momento seguinte. As pessoas más - não obstante a opinião em contrário de Aristóteles - não são 'cheias de remorsos'.

Por esse viés, assim como o pensar, tal como fora abordado, é possível a todos os seres humanos, o não pensar, também, é um fenômeno que pode ser concebido por qualquer sujeito - seja ele erudito, cientista ou político -, todos podem se desviar dessa busca que corresponde ao pensamento (ARENDT, 2009). Por ora, esse fato causa espanto, porque, comumente, atribui-se aos intelectuais essa atividade do espírito. No entanto, o intelecto se liga à cognição relativa ao conhecimento.

Para sustentar esse argumento, Arendt recorre à distinção postulada por Kant (2015), em sua obra Crítica da razão pura, na qual a faculdade da cognição (Verstand intelecto) difere da faculdade do pensar (Vernuft - razão). Com isso, a autora considera que é singular ao intelecto chegar à verdade por meio da indagação "do que uma coisa é ou se ela existe"; por outro lado, a razão guia-se a compreender o significado de modo que evoca "o que significa, para ela" (a coisa), "ser" (ARENDT, 2009, p. 75). Nota-se, aqui, que os sujeitos que se dedicam aos processos de apreensão daquilo que se dá à percepção, como citados anteriormente, podem não se empenhar na atividade do pensar, cujo caráter é altamente corrosivo sobre as certezas humanas.

Fica perceptível, então, que maus cometidos em pequenas escalas e que, contudo, tomam grandes proporções são frutos da irreflexão em uma vida burocratizada estabelecida por via da subordinação às ordens e doutrinas. A lógica da ideia, perpassada pela ideologia, concerne à banalização da violência em alta escala, que se alastra pela sociedade e é pautada na inversão dos valores morais. A obediência, por conseguinte, toma papel principal nessas sociedades, onde o vento do pensamento poderia colocar tudo a ruir, pois, como ressalta Arendt (ARENDT, 2009), não existem pensamentos perigosos. O próprio pensamento é perigoso.

\section{CONSIDERAÇÕES FINAIS}

Diante de tal análise acerca do pensamento arendtiano, percebe-se, portanto, que a figura histórica de Adolf Eichmann representa, também, a de muitos outros que viviam em regimes totalitários e que, segundo Arendt (2009, p. 18), eram atingidos pela falta de pensamento, adotando regras de condutas provenientes da irreflexão; ou seja, na ausência de busca de sentido para os fatos enfrentados na vida cotidiana.

Igualmente, somos conduzidos a considerar que seria o pensamento em seu caráter crítico e dialético uma condição para evitar as catástrofes que marcaram o século XX na medida em que se nota uma possível relação entre a correspondência do pensamento e as boas ações, e a irreflexão e os atos maus. Essa faculdade do espírito humano, no sentido abordado por Arendt, torna-se uma outra via para compreender o mundo e se guiar na esfera da ação quando a moralidade vigente se baseia na deturpação da realidade e na mentira cínica.

Notamos, por fim, que o mal banal, proveniente da irreflexão, perdura dentro das diferentes configurações políticas hodiernas, cujas cadeias de violências se repetem a partir da figuração de regras de conduta consoante a superficialidade humana. Nessa perspectiva, salienta Abranches (1993, p. 13): “A sobrevivência de 'elementos' totalitários em regimes não totalitários continua a ser uma ameaça tão mais poderosa quanto mais recoberta estiver pelo esquecimento e pela subsequente paralização de um pensamento que se encontra 
impedido de começar a pensar". Isso consolida a emergência do pensar para romper com as compreensões totalitárias de mundo que transgridam a linha limítrofe entre a esfera privada e a pública.

\section{REFERÊNCIAS}

ABRANCHES, Antônio. Introdução - Uma herança sem testamento. In: ARENDT, Hannah. A Dignidade da Política. Tradução Helena Martins Frida Coelho, Antônio Abranches, César Almeida, Cláudia Drucker e Fernando Rodrigues. Rio de Janeiro: Relume-Dumará, 1993. p. 7-14.

ARENDT, Hannah. Origens do Totalitarismo. Tradução Roberto Raposo. São Paulo: Companhia das Letras, 1989.

ARENDT, Hannah. A Dignidade da Política. Tradução Helena Martins Frida Coelho, Antônio Abranches, César Almeida, Cláudia Drucker e Fernando Rodrigues. Rio de Janeiro: RelumeDumará, 1993.

ARENDT, Hannah. The Human Condition. Chicago: University of Chicago Press, 1998.

ARENDT, Hannah. Eichmann em Jerusalém: um relato sobre a banalidade do mal. Tradução José Rubens Siqueira. São Paulo: Companhia das Letras, 1999.

ARENDT, Hannah. A condição humana. Tradução Roberto Raposo. Rio de Janeiro: Forense Universitária, 2007.

ARENDT, Hannah. A Vida do Espírito - O pensar, o querer, o julgar. Tradução Antônio Abranches, César Augusto de Almeida e Helena Martins. Rio de Janeiro: Civilização Brasileira, 2009.

CORREIA, Adriano. Arendt e Kant: banalidade do mal e mal radical. Argumentos, Fortaleza, n. 9, p. 63-78, 2013. Disponível em: <http://repositorio.ufc.br/handle/riufc/23746>. Acesso em: 19 jan. 2021.

HOBSBAWM, Eric. Era dos extremos: o breve século XX: 1914-1991. Tradução Marcos Santarrita. São Paulo: Companhia das Letras, 1995.

KANT, Immanuel. Crítica da razão pura. 4. ed. Petrópolis: Vozes; Bragança Paulista: Editora Universitária São Francisco, 2015.

SCHIO, Sônia Maria. Hannah Arendt: o mal banal e o julgar. Veritas, Porto Alegre, v. 56, n. 1, p. 127-136, 2011. Disponível em: <https://revistaseletronicas.pucrs.br/index.php/veritas/article/ view/9297/6407>. Acesso em: 8 jan. 2021.

SOUKI, Nádia. Hannah Arendt e a banalidade do mal. Belo Horizonte: UFMG, 1998.

\section{NOTAS}

1 Como grande expoente desse acontecimento, há os "Julgamentos de Nuremberg", que aconteceram de 20 de novembro de 1945 a $1^{\circ}$ de outubro de 1946.

2 O Terceiro Reich (Das Dritte Reiché) foi uma forma nominal comumente utilizada pelos veículos de propaganda nazista. Em sua tradução literal para o português, equivale ao termo "império". Assim, constituiu-se na tentativa de Hitler de consolidar o Império Alemão seguindo uma lógica histórica que parte do Primeiro Reich - o Sacro Império Romano da Nação Alemã (908 d.C.-1806) e do Segundo Reich - a Alemanha unificada (1871-1918) por Otto von Bismarck.

3 Arendt (2009, p. 153), em sua obra A Vida do Espírito, faz uma referência ao papel do espectador atento ao mundo e às suas manifestações: "Sem espectadores, o mundo seria imperfeito. $\mathrm{O}$ participante absorvido em coisas específicas e pressionado por afazeres urgentes não pode ver como todas as coisas particulares do mundo e como todos os feitos particulares ajustamse uns aos outros e produzem uma harmonia que não é, ela mesma, dada à percepção sensorial. Esse invisível no visível permaneceria para sempre oculto se não houvesse um espectador para cuidar dele, admirá-lo, endireitar as histórias e pô-las em palavras”. Cabe, aqui, perceber a autora como essa espectadora atenta ao julgamento; portanto, capaz de analisá-lo meticulosamente e transpô-lo em palavras.

4 Em torno desta questão, a superficialidade e a radicalidade do mal, há um debate que discute em qual medida esses dois conceitos se excluem ou se complementam. 
5 A princípio, uma pequena unidade paramilitar, composta por homens disciplinados e racialmente selecionados. Sob ideologia nazista, a SS exerceu grande importância no Reich ao comando de Heinrich Himmler. Este comandava a polícia secreta nazista, o órgão que controlava as polícias e o serviço de inteligência, além de ter um exército próprio. Posteriormente, comandou os campos de concentração nos países ocupados.

1146 Título existente na SS, no período de 1925 a 1945, que se tornou a patente mais alta.

7 Diretor do Escritório de Segurança do Reich (RSHA), responsável pelo Protetorado da Boémia e Morávia e Diretor da Gestapo.

8 Sobre isso, destaca Arendt (1999, p. 58): "Ele imaginou 'uma linha de montagem, na qual o primeiro documento era posto no começo, depois iam sendo inseridos os outros papéis, e no final o passaporte teria de sair como produto final"'.

9 Tal concepção fez com que a palavra "assassinato" fosse substituída por "dar uma morte misericordiosa" ao se referirem à morte na câmera de gás (ARENDT, 1999, p. 125).

10 Referindo-se a essa questão, diz Arendt (1993, p. 151): "Daí decorre, aparentemente, a ideia de que a atividade do pensamento é como a teia de Penélope: desfaz-se toda manhã o que foi terminado na noite anterior".

11 Em sua obra A Vida do Espírito, Arendt (2009, p. 211-213) faz referência a Shakespeare para tratar do dois-em-um socrático por meio de um soneto do rei Ricardo III, no qual ele retrata o seu diálogo interior com a sua consciência moral, que lhe faz cobranças pelos seus crimes cometidos. 